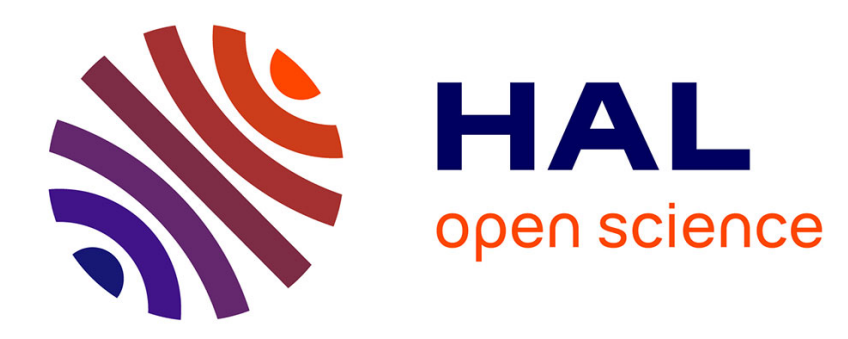

\title{
Domesticating Transport: the Sensory Experience of Work-Related Travel
}

\author{
Nathalie Ortar
}

\section{To cite this version:}

Nathalie Ortar. Domesticating Transport: the Sensory Experience of Work-Related Travel. Senses and Society, 2016, Contemporary French Sensory Ethnography, 11 (3), pp.275-285. 10.1080/17458927.2016.1195110 . halshs-01380670

\section{HAL Id: halshs-01380670 \\ https://shs.hal.science/halshs-01380670}

Submitted on 6 Dec 2017

HAL is a multi-disciplinary open access archive for the deposit and dissemination of scientific research documents, whether they are published or not. The documents may come from teaching and research institutions in France or abroad, or from public or private research centers.
L'archive ouverte pluridisciplinaire HAL, est destinée au dépôt et à la diffusion de documents scientifiques de niveau recherche, publiés ou non, émanant des établissements d'enseignement et de recherche français ou étrangers, des laboratoires publics ou privés. 
DOMESTICATING TRANSPORT:

THE SENSORY EXPERIENCE OF WORK-RELATED TRAVEL

Translated by Carmen Ruschiensky

The Senses and Society, vol. 11, n³, Pages 275-285

\author{
Nathalie Ortar \\ Research Fellow at the LAET \\ ENTPE \\ Rue Maurice Audin \\ 69518 Vaulx-en-Velin cedex \\ Nathalie.ortar@entpe.fr
}

Nathalie Ortar is an anthropologist and a Research Fellow at the Laboratoire d'aménagement et d'économie des transports (LAET) of the École nationale des travaux publics de l'État (ENTPE). Her research focuses on an anthropology of habitation interpreted through the prism of everyday life and residential, professional and social mobility.

Nathalie.ortar@entpe.fr

\begin{abstract}
:
Whether leaving early, arriving late, or travelling at night, the particular temporality of workrelated travel entails travelling in moments of fragility, when the body is in need of rest and particularly vulnerable to different sensory experiences and intrusions. To cope, mobile workers have to domesticate their spaces of transit and create habits to make the places and spaces encountered through the body their own. Unlike the traveller who goes on vacation to take a break from his or her day-to-day life, workers on the move construct continuities in their ruptured experience to maintain the equilibrium that structures their professional and nonprofessional time in movement, which is punctuated by technical, climactic and/or temporal uncertainties, hindrances to finding one's bearings. Moving week after week is therefore a multidimensional experience that engages the body and appeals to the senses. How does the body, as a vehicle of memory, engage different ways of thinking and acting in the present while confronting disruption? The following observations and analyses are informed by different traditions of French research that seek to analyze sensoriality in particular and understand, more broadly, what motivates behavioral change.
\end{abstract}

Keywords: routines, travel, coping mechanisms, senses

Samuel leaves his Lyon residence at 11:30 on Sunday night, having slept two hours. He takes the last bus, which brings him one hour too early to the train station, where he finds other night travellers who, like him, are waiting to take the 1 a.m. southbound-TGV train. Before leaving home, he makes sure he has his hat and scarf for the anticipated wait on the platform, and he puts on an extra sweater, even during summer. Once aboard the train, he seeks out two vacant 
seats side-by-side: the train will not be stopping before Toulon five hours later, so he can occupy other seats besides the one he reserved. Having barely settled in, he takes out an inflatable headrest and sleeping mask and tries to find a comfortable position, wrapping himself in his jacket, which is never quite large enough to keep out the cold during the night. A blanket or sleeping bag would take up too much room in his luggage, which he will later have to carry between his different places of residence and work. He then pulls on a pair of ski socks. Others have sleeping bags that they lay out directly on the floor as soon as the ticket inspector has passed. As regular travellers, they all have their tips and tricks for delaying the inevitable aches that come with trying to sleep in the contorted positions the cramped space imposes on them. It is not a question here of getting a refreshing sleep but of being the least tired possible upon arrival.

These travellers ${ }^{1}$ include executives criss-crossing France or the world to meet clients, workers heading to construction sites or providing services to customers, and sales representatives, as well as many other men and women who, for various personal or professional reasons, do not live in the same place where they work. For all of them, travelling is a weekly practice. The modes of transportation are varied, from cars and airplanes to trains and ferries. Some trips involve only one type of transportation; others combine many depending on the places of residence or employment, but also the nature of the work. Having arrived at their place of work, they stay in hotels, with friends or family, on a folding bed set up in their office, in a trailer or in a rented or purchased apartment. From one week to another or, sometimes, over the course of the same week, the places of stay vary.

Whether leaving early, arriving late, or travelling at night, the particular temporality of workrelated travel, allowing as much time as possible for family life, entails travelling in moments of fragility, when the body is in need of rest and particularly vulnerable to different sensory experiences and intrusions. Unlike the traveller who goes on vacation to take a break from his or her day-to-day life, workers on the move construct a continuity of habits to maintain the equilibrium that structures their professional and non-professional time in movement, which is punctuated by technical, climactic and/or temporal uncertainties, hindrances to finding one's bearings. If, as David Le Breton writes, "everyday life is the adult's safe haven" (2008: 93), to cope, travellers have to domesticate their spaces of transit and create habits to make the places and times of travel their own. Moving for a few days week after week to practice one's profession engages the body and the senses. Managing these particular periods of everyday experience entails acquiring bodily techniques, automatic reflexes that ensure the voyage takes place along a continuum that is integrated into other daily practices.

The travel experience conveys the raw reactions of the body in a state of interrupted learning as well as the different coping mechanisms that individuals turn to in order to adapt. Indeed, "the senses are not 'windows' onto the world, 'mirrors' that record things with total indifference to cultures and sensibilities; they are filters that retain in their sieve that which the individual has learned to put there" (Le Breton 2007: 47). Travelling also reveals the content of our filters, the importance of routines, and the limits of learning. Decoding these attachments implies describing different sensory experiences in order to understand the hierarchy of the senses (Corbin 1990), discern the fissures and disruptions imposed by travel, and account for the importance of the body's memory (Candau 2010). It entails, therefore, considering the senses in interaction with one another (Gélard and Sirost 2010). This article discusses the disruption of the senses that travelling induces and the techniques employed to counterbalance its effects by establishing routines, on the one hand, and managing sensory experiences, on the other.

\footnotetext{
${ }^{1}$ This article is the result of research conducted from 2006 to 2007, in collaboration with Caroline Legrand and funded by the French Environment and Energy Management Agency (ADEME).
} 


\section{Practices and routines}

Reality becomes intelligible within an ensemble of habits and routines that punctuate everyday life. These are regulated by corporeal attitudes and gestures specific to each social situation, because the "operations ordered by the body play an essential role" in interactions that allow individuals to take full measure of their belonging in the world through a unique "style of vision, touch, hearing, taste and smell" (Le Breton 2008: 150, 159). Our daily lives are thus structured by tasks rendered invisible through repetition (Certeau 1990; Kaufmann 1997). As Ehn and Löfgren observe in their work on the art of doing nothing: "The often voiced feeling about the chaos of contemporary life, about life being in constant change and flux, needs to be contrasted with the insight that most of our activities are in fact constantly repeated and predictable. Repetitive actions create the backbone of people's lives. We only notice them when they break down or are challenged" (2010: 120). Mobility, however, creates discontinuity within continuity and makes daily routines precarious, for lack of sufficient repetition.

The quality of the sensory experience of travel is affected by the preservation of daily habits, the level of physical and thermal comfort, and the ability to manage time and maintain connections with family. However, travelling also involves a body language, a set of procedures, an integration of rules that vary from one place or mode of transport to another, and a fine-tuned knowledge of the physical twists and turns of different spaces of transit, as well as local customs. From the family residence to the rest areas and spaces traversed during the week, the mobile worker is continually discovering new ways to restore routines, even though certain sensory experiences - the pleasure of sitting down to eat, for example - cannot be satisfied. Leaving early, getting home late, and eating on the go disrupt alimentary rhythms, and travellers find themselves eating when not hungry, staving off hunger, or gulping down whatever is on hand.

Travelling in comfort requires preparing for the unpredictable and circumventing constraints. This entails organization and an ability to foresee different travel situations as a whole. The price of this is a mental overload, an omnipresence of displacement that spills over into the everyday life of the family. Forgetting the slightest detail can affect the experience of the voyage, because habit is the ability to give one's current existence a sense of continuity (Goffman 1973). Aymeric is a technician who works on installing and maintaining ski lifts in the mountains. His working hours on site are very long - well beyond legal limits, as is often the case in unregulated work situations requiring travel - so he does not have access to stores. His toothbrush plays a role in his daily cleansing rituals. Forgetting it upsets his sense of personal balance because it affects his bodily sensations, notably of well-being, but also his bedtime and morning rituals. His clothing possesses this same status of conveyor and protector of everyday life. The physical discomfort of not having clean clothes or wearing an inappropriate or damp outfit reinforces the feeling of strangeness that he experiences.

The tactics employed to claim space and keep the other at a distance while travelling illustrate how access to the familiar is preserved. Just as a person's choice of clothing can be a source of comfort and familiarity, the choice of seats on a train or airplane also provides access to the familiar through different sensations and body movements. It is a question of marking public territory (Goffman 1973) to lay claim to it. On the train, the first element sought out is space in the form of an extra vacant seat. This extra space allows the traveller to spread out both literally and figuratively: stretching out his or her legs in a way that is less constraining, to the side or on the adjacent seat, spreading out folders and other belongings when it is time to work in order to signal to others that their presence is unwelcome. The second form of distancing is physical - using the armrest without touching elbows to remind one's neighbor it is shared, 
avoiding inadvertently brushing against the neighbor's leg or stepping on his or her feet when getting up.

Keeping others at a distance is also about not having to endure intrusions into one's "membrane" (Goffman 1961) or "protective bubble" (Pétonnet 1987) and therefore travelling without being subjected to visual intrusions, such as images emanating from screens or other kinesthetic and olfactory intrusions that can be seen as encroaching upon one's personal space in a society where contact is coded (Elias 1991; Goffman 1974). Keeping one's distance from the other also involves guarding oneself against intrusive looks. Travellers adopt certain postures and attitudes while reading, working or watching movies to avoid being judged by neighboring passengers, who might be reading over their shoulders or noticing their choice of films. The traveller thus develops a savoir-faire that involves feigning indifference to the other's gaze and neutralizing its presence without pretending to be totally unaware of it.

Hearing is also disrupted. Being in one's bubble entails guarding against not only visual contact but also against the sounds emitted by neighboring passengers. The widespread use of mobile phones and portable devices has added new auditory intrusions, which are no longer limited to the conversations of unapologetically talkative neighbors, but now also include telephone monologues and distorted sounds emanating from headphones. Travellers play their own music or equip themselves with noise-cancelling headphones in order to avoid annoyances but also to recreate a personal universe. They are thus able to maintain a space of familiarity in spite of the anonymity and discomfort that the close quarters impose on them.

The senses are also used to satisfy and reassure. The landscapes traversed week after week have a double visual appeal. On the one hand, the recognizable places create a familiar universe, on the other, the aesthetic pleasure afforded by views of the passing scenery reaffirm the traveller's choice of lifestyle and justify the distance between family life and work. In a society that privileges vision over the other senses (Gélard 2012; Le Breton 2007), this visual satisfaction reinforces the traveller's life choices and provides a feeling of physical and moral well-being that is part of the sensory experience of travel. Landscapes also serve as reference points, landmarks of the transition between the domestic and professional universes that mark out the voyage but also give it meaning. They reintroduce continuity in discontinuity. Indeed, if these traversed places are really non-places (Augé 1992), since the traveller does not stop to visit them and will never explore them on foot, they are no less filled with significance. The travel experience is thus based on the creation and maintenance of familiar rituals intended to produce pleasant sensory experiences while neutralizing others.

Domesticating transport is learning to be at one with displacement. The rigid framework of the experience - the compartment of a car, train or airplane - the obligation to fix the body's limits, the temporality imposed by the duration of the trip, the exposure to variations in temperature and to different odors, sounds, undesired physical contacts, and incivilities are among the intrusive and disruptive elements that impinge on the traveller in situations of "distension or suspension of shared-knowledge connections" (Jarrigeon 2012: 195) to which the body is exposed. As Marcel Mauss (1934) has noted with reference to the supports, rules, norms, spatio-temporal markers, and perceptual indices originating in early experiences, techniques of rest and sleep acquired from birth are difficult to cast off, thus impeding one's ability to adapt to other frameworks of experience. Incorporating the characteristics of a place, adapting, say, a piece of furniture normally intended for sitting, disturbs one's rest habits. Likewise, sleeping during periods normally devoted to wakefulness while traveling, then trying to sleep again once at home, or, inversely, cutting one's sleep short only to pass the rest of the night sitting upright, modifies physiological rhythms and resting techniques, undermining the cultural coping mechanisms that contribute to a person's well-being as well as the body's physiological ability to recuperate. 


\section{Sensory experiences and attachments}

Maintaining the armature of routines while being on the move week in week out therefore necessitates multidimensional learning (Eric Le Breton 2008) based as much on how-to-be as how-to-do, in order to leave as little to chance as possible. Expertise is reflected in the acquisition of "tips and tricks" devised along the way and/or advice from people who have already been subjected to similar constraints. Paul is a manager who has just been transferred to an international position to supervise his company's factory operations. The length of his absences varies from one week to the next. To manage this, he possesses an array of suitcases adapted to different upcoming trips. While the suitcase's size affects its status as checked baggage and its weight, the overall length of the trip and expected fatigue upon arrival are also considered, given that handling it adds a physical burden and hampers movement. Even towed, a suitcase strains the arm and shoulder and weighs heavily, when, in the absence of escalators and elevators, it has to be lifted one stair at a time. Ease or difficulty handling luggage influences the fluidity of movement, the level of both physical and moral fatigue, the sense of constraint experienced and thus the overall feeling of the trip. Checking one's suitcase also increases the risk of error between flight connections and entails having a carry-on emergency pack and change of clothes to avoid being uncomfortable while waiting for the missing baggage. Travelling is therefore learning to both cope with and anticipate uncertainties to maintain the body and the senses in a state of comfort.

While the civilizing process seems to have accelerated, and individuals, particularly mobile workers, find their time more and more constrained (Rosa, 2010), travel time is paradoxically defined by a slackening of temporal constraints, introducing a space-time of inhabitual vacuity in the course of everyday life. Moreover, as a voyage, it becomes a liminal zone between the professional and the personal. Mastering the ability to fill the time of inaction during travel influences a person's physical perception of the voyage as well as its felt duration. The corpus of activities created helps pass the time. For executives, reading predominates during train or airplane trips (Lyons and Urry 2005) due, on the one hand, to the large number of documents that still have to be read offline and, on the other, to the significant periods of uninterrupted time, which encourage activities demanding sustained attention that are difficult to perform at the office. Damien is an international business executive. He has to leave home early and begins his trips by sleeping as soon as he has boarded. He reads his documents later. Travel time is not a priori dead time (Sheller and Urry 2006) and can even be an opportunity to indulge in pleasure (Lyons and Urry 2005). Claudia is also a business executive, and she travels a lot in Scandinavia. She has little time to read in her day-to-day life but takes advantage of her waiting time in airports to lose herself in reading. Watching movies and listening to music are other activities that encourage escape. Through all of these activities, travellers have access to other illusory, domestic or professional universes to avoid thinking about their condition as passengers and change their perception of the present moment. Whether professional or personal, these activities have to be planned and organized with the same rigor devoted to the overall trip. This means, once again, being prepared and organized to assure a continuity of activities that make sense.

The constant attention required to organize everything down to the last detail makes the equilibrium of these experiences fragile. The uncertainties of travel and accumulated fatigue undermine acquired routines. Delays, for example, create instability and upset established patterns. Being late is exasperating when going to work and irritating when returning home. These delays can be insignificant in and of themselves, but, during the periods they take place, they compromise the planning of the family evening, because catching the next bus or train depends on timely arrival. Being in a state of standby and continually seeking information 
causes discomfort and compromises the quality of the trip, because the act of waiting eventually invades one's entire mental space and dominates all other experiences.

Creating a circle of activities does not, in the long run, suffice to pass the time and forget the constraints of staying in new places and the physical constraints provoked by anticipated sleep interruptions, late bedtimes, and the disrupted rhythm of meals. These disruptions give rise to a sensation of malaise and produce, in the end, a sensation of unreality related to persistent discomfort. As Maurice Godelier and Michel Panoff have observed (1998: xviii), the body is both a cultural entity "that animates and especially controls actions" and a combination of substances, organs and functions. The wear and tear produced by the discomfort of travelling reveals the impossibility of overcoming the body's physiological limits and the capitulation of the cultural in a society where bodily weakness is synonymous with failure (Vigarello, 2014). The coping mechanisms that are found or created are never sufficient to achieve a complete sense of well-being and forget oneself. Transporting luggage that strains the same muscles, eating meals that were not really chosen, and sleeping in unknown places all disturb one's internal order, exacerbate negative sensory experiences, and impede the establishment of new routines, even as old ones must be maintained to recover the familiarity of home. Since habits are never totally routinized due to insufficient repetition, maintaining them demands an effort that becomes a burden over time, and interest or pleasure become difficult to sustain. Experience, rather than improving one's perception of travel, tends to reinforce the asperities and constraints. The moments of travel that mobile workers value in the beginning - getting work done, cultivating oneself, or relaxing - gradually become empty moments, periods of sleepiness and waiting between two destinations. Eventually, mobile workers are no longer able to mobilize the energy needed to make these moments enjoyable and/or constructive.

In the end, travel schedules that lengthen the work day without allowing any real time to recuperate at home or on the job, fear of the unexpected, notably when mobile workers depend on schedules set by airline companies or juggle between several modes of transport, the tiring impression of being constantly on the move, the weariness of waiting for the trip to end in train stations, airports, trains and airplanes, stuck in one's seat, all gradually undermine and subsume mobile workers' overall sensory experience and dominate their day-to-day lives even at home.

Preparing for travel in order to ensure comfort and manage one's sensory experience invades the short periods dedicated to family life. Though making sure the travel kit is ready and complete on time guarantees a certain control over comfort while travelling, it represents an additional mental load during time spent with family. It requires thinking about the next trip in moments that should be dedicated to forgetting about travel and impedes the recovery of automatic reflexes. These embedded temporalities, and the daily routines associated with them, are too interwoven, making it difficult for mobile workers to adapt from one rhythm to another or from one lifestyle to another without effort. In this way, mobility and the unpleasant effects it has on travellers invades, little-by-little, all of their temporal experiences.

Travel requires a preparation and reflexivity regarding the conditions of well-being that oblige travellers to make the non-thoughts of everyday life explicit, both for adapting to displacement and for maintaining one's bearings in the family home, when, for lack of sufficient practice, routines are no longer self-evident. These moments of forgetting reveal the importance, as well as the fragility, of the different coping mechanisms that sustain routines in sensory equilibrium to get through everyday life without discomfort. The disruption introduced by travel highlights the importance of physical behaviors and sensory experiences in the normal course of one's life, their acquired character, and the difficulty in adapting them or developing new ones when the stability of everyday life - and therefore learning through repetition - is not assured. What emerges from this is the importance of satisfying the physiological body's needs 
as well as the on-going process of learning that adults engage in to naturalize cultural functions and put them into practice.

\section{Bibliography}

Augé M. 1992. Non-Lieux. Introduction à une anthropologie de la surmodernité. Paris: Le Seuil.

Candau J. 2010. “Intersensorialité humaine et cognition sociale.” Communications 86: 25-36.

Certeau M. (de). 1990. L'invention du quotidien, I: Arts de faire. Collection Folio essais 146. Paris: Gallimard.

Corbin A. 1990. "Histoire et anthropologie sensorielle." Anthropologie et Sociétés 14 (2): 1324.

Ehn B., Löfgren O. 2010. The Secret World of Doing Nothing. Berkeley: University of California Press.

Elias N. 1991. La société des individus. Paris: Fayard.

Gélard M.-L. and Sirost O. (eds.). 2010. "Le langage des sens.” Communications 86.

Gélard M.-L. 2012. Ethnographie d'un horizon parentaire Kabylie, Haut Atlas Et Sahara Des Aït Khebbach à l'anthropologie sensorielle. Mémoire d'Habilitation à Diriger des Recherches. Volume 1. Aix-Marseille Université.

Godelier M. and Panoff M. 1998. "Introduction." In Godelier M. and Panoff M. (eds.) La production du corps. Approches anthropologiques et historiques. Paris: Editions des archives contemporaines, $\mathrm{xi}-\mathrm{xxv}$.

Goffman E. 1961. "Fun in games." In Encounters: Two Studies in the Sociology of Interaction. Indianapolis: Bobbs-Merrill.

Goffman E. 1973. La mise en scène de la vie quotidienne, Vol. II Les relations en public. Paris: Minuit.

Goffman E. 1974. Les rites d'interaction. Paris: Editions de Minuit.

Jarrigeon A. 2012. "Des corps aux lieux urbains, habiter les espaces publics." In Morel-Brochet A. and Ortar N. (eds). La fabrique des modes d'habiter. Hommes, lieux et milieux de vie. Paris: L'Harmattan coll. Habitat et sociétés, 195-210.

Kaufmann J.-C. 1997. Le Cour à l'ouvrage. Théorie de l'action ménagère, Paris: Nathan.

Le Breton D. 2007. "Pour une anthropologie des sens." érès |VST - Vie sociale et traitements 4 (96): 45-53.

Le Breton D. 2008. Anthropologie du corps et modernité. Paris: PUF. Quadrige Essais Débats.

Le Breton E. 2008. Domicile/travail : les salariés à bout de souffle. Paris: Les carnets de l'info. Modes de ville.

Lyons G. and Urry J. 2005. "Travel Time Use in the Information Age." Transportation Research Part A 39: 257-276.

Mauss M. 1934. "Les techniques du corps." Les classiques des sciences sociales. Web site: http://www.uqac.uquebec.ca/zone30/Classiques_des_sciences_sociales/index.html

Pétonnet C. 1987. "L'anonymat comme pellicule protectrice." In La ville inquiète, Le temps de la réflexion VII. Paris: Gallimard, 247-261. 
Rosa H. 2010. Accélération. Une critique sociale du temps. Paris: La découverte.

Sheller M. and Urry J. 2006. "The New Mobilities Paradigm." Environment and Planning A 38 (2): 207-226.

Vigarello G. 2014. Le sentiment de soi. Histoire de la perception du corps. Paris: Seuil. 